\title{
COLLECTING BEETLES IN AN ACID PITCHER PLANT BOG
}

RONALD R. HOOPER, Box 205, Fort Qu'Appelle, Saskatchewan. SOG 1 S0

On 24 and 25 June 1981 I spent an enjoyable time for a part of two days collecting insects in a Pitcher Plant bog near Greenbush campsite, west of Hudson Bay, Saskatchewan. I was on a collecting trip for the Saskatchewan Provincial Museum, accompanied by my brother Don and his friend Les Baker, who were collecting plants.

The usual bog species of butterflies such as Bog Fritillary (Bo/oria eunomia dawsoni (Barnes and McDunnough)), Jutta Arctic (Oeneis jutta ridingiana (Chermock and Chermock)), and Mancinus Alpine (Erebia disa mancinus (Doubleday)) were present. One Grizzled Skipper (Pyrgus centaureae freija (Warren)) was also seen.

Day-flying moths were uncommon, so not many were taken. Dragonflies were plentiful near Shenigan Lake, including the beautiful Ladona julia (Uhler) which is dusted with bluish-white at the base of the thorax and abdomen.

Mosquito larvae were found in the water in the Pitcher Plant leaves and were presumably those of the Pitcher Plant Mosquito (Weomyia smithii Coq.)

The most noteworthy of all were the beetles. These were mostly collected by tramping the floating sphagnum moss down into the little puddles of water, and then going through the water with an aquatic net. The following is a list of the species that were taken.

\section{Species List}

GROUND BEETLES (CARABIDAE)

Blethisa quadricollis (Haldeman) - Three specimens in floating moss near Shenigan Lake. About $16 \mathrm{~mm}$ long. Black, with metallic purple sheen. Elytra indented with rows of both fine and coarse pits. First Saskatchewan record. Recorded previously in both Manitoba and Alberta.

Blethisa multipunctata (Linnaeus) - One specimen. Occasionally found in marshes throughout Saskatchewan.

Carabus chamissonis (Fischer) - Abdomen and elytra of one specimen found in a Pitcher Plant leaf. Taken previously in Saskatchewan at Waskesiu and Prince Albert.

Bembidion interventor (Lindroth) -- One specimen. Apparently a stray into the bog. This species was common on dry sand among the jackpines about a half a mile farther east.

Agonum mutatum (Gemminger and Harold) - Eleven specimens in floating moss near Shenigan Lake. $8 \mathrm{~mm}$ long, and black in colour. First Saskatchewan record. Recorded previously (by Lindroth) west to Manitoba, and also in British Columbia and Alaska. It probably occurs in the right habitat across Northern Saskatchewan and Alberta.

Amara lacustris (LeConte) - One elytra in Pitcher Plant leaf. This common species is usually found along shores.

Chlaenius pensylvanicus (Say) - One specimen in wet moss near Shenigan Lake. This species is very common throughout Southern Saskatchewan under debris along wet shore-lines.

\section{PREDACEOUS DIVING BEETLES}

(DYTISCIDAE)

Hygrotus sayi (Balfour-Brown) - One specimen of this common Saskatchewan species was collected.

Hydroporus rectus (Fall) - One specimen collected. Taken previously in a floating moss bog at Milliken Lake, near Uranium City. 
Hydroporus striola (Gyllenhal) - Fifteen specimens. A common species of floating bogs.

Hydroporus (near) hockingi (Larson) - Two specimens. H. hockingi was named by David Larson from specimens taken in sphagnum bogs in the foothills of Alberta. More collecting needs to be done to find out if this is a different species, or a variant of $H$. hockingi.

Agabus phaeopterus (Kirby) - Three specimens. Taken previously in Saskatchewan at Patterson Lake. It should be found throughout the forested area of the province.

Agabus semipunctatus (Kirby) - Four specimens. Taken previously in Saskatchewan at Milliken Lake, near Uranium City.

llybius discedens (Sharp) - Sixteen specimens. Common in Northern Saskatchewan.

Dytiscus harrisii (Kirby) - One male specimen found dead. This is an uncommon species that is found across the Canadian Zone.

Dytiscus circumcinctus (Ahrens) - Elytra of two specimens of this very common species were found.

Hydaticus modestus (Sharp) - One elytron found of this occasional species.

\section{WATER SCAVENGER BEETLES (HYDRPHILIDAE)}

Crenitis morata (Horn) - Three specimens. Cymbiodyta acuminata (Fall) - Eight specimens.

Cymbiodyta sp. - One specimen.

Cercyon cinctus (Smetana) - Two specimens.

ROVE BEETLES (STAPHYLINIDAE)

Gymnusa atra (Casey) - One specimen.

CLICK BEETLES (ELATERIDAE)

Ctenicera sp. - One specimen, swept from Leatherleaf.

SOLDIER BEETLES (CANTHARIDAE)

Cantharis sp. - Nineteen specimens from Pitcher Plant blossoms. The same species was taken on Pitcher Plants at Nipawin on 15 June 1968.

\section{LADY BEETLES (COCCINELLIDAE)}

Coccidula occidentalis (Horn) - One specimen, swept from Leatherleaf. This is a marsh species of the Canadian Zone.

\section{WEEVILS (CURCULIONIDAE)}

Hypomelyx piceus (DeG.) - The elytra and abdomen of one specimen were found in a Pitcher Plant leaf. We have previous records of this holarctic species from Somme and Waskesiu.

\section{Acknowledgements}

I am indebted to Dr. George Ball of Edmonton, Alberta, for checking the identifcation of the Ground Beetles, and to Dr. David Larson of Saint John's, Newfoundland for checking the identification of the Predaceous Diving Beetles.

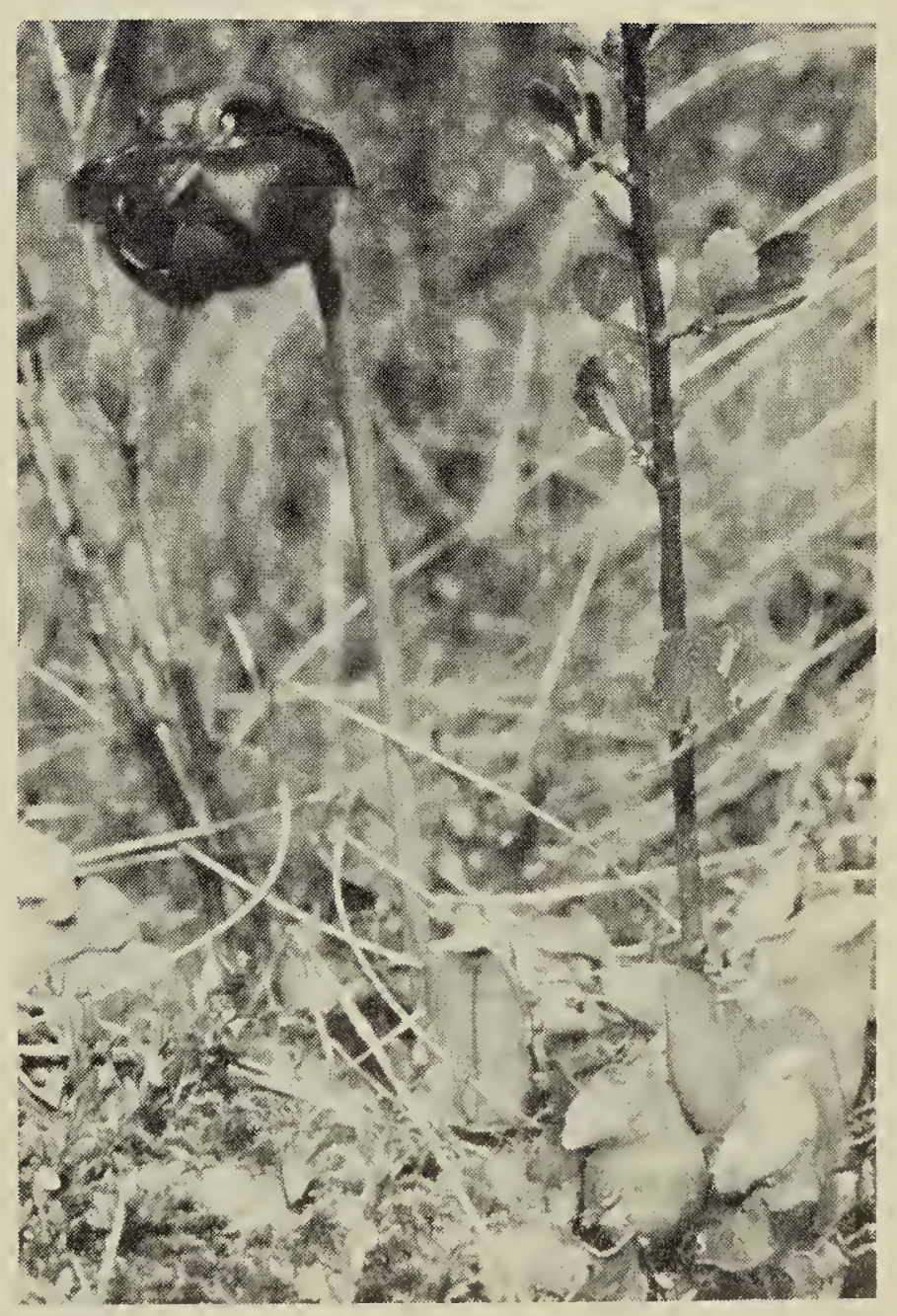

Pitcher Plant

Ron Hooper 